\title{
Russian Digital Economy: State and Development Prospects
}

\author{
Natalya L. Udaltsova \\ Department of Management \\ Financial University under the Government of the Russian Federation \\ Moscow, Russian Federation \\ udaltsova.nl@yandex.ru
}

\begin{abstract}
This scientific article covers the conceptual framework of digital economy and the influence thereof on the development of world economic processes, and investigates the efficiency of digitalization process development in Russia and in some other countries. According to estimates of consulting companies, the digitalization of the Russian economy has a potential effect of 4.1-8.9 trillion roubles for GDP, which will amount to approximately $19-34 \%$ of the total increase of GDP by 2025 . Russia has all necessary prerequisites for the achievement of the digital potential. In order to achieve this, first of all, it is necessary to determine the technological focus and to concentrate investment opportunities on the goals set, to develop the innovation culture in all possible ways on the model of the country's digital companies. Another important task that requires a timely solution will be the education area and training of specialists. It is obvious that the digitalization will lead to emergence of new professions and obsolescence of some existing professions.
\end{abstract}

Key words: digital economy, Industry 4.0, information and telecommunication technologies.

\section{INTRODUCTION}

The modern development of information and telecommunication sector and its accompanying technologies significantly change the relations in the society. Therefore, one may observe the formation and further development of the information society which is called the "digital economy". It is obvious that digital technologies have become an integral part of social and economic life of the society and a key direction for the development of the state policy at the modern stage. As a matter of fact, the economy digitalization process is a process of change of the technological scheme and production process. To all intents, we talk about another industrial revolution "Industry 4.0" presenting a serious challenge for the international community, economies and companies all over the world that should be ready for it. The concept of the fourth industrial revolution (Industry 4.0) was stated in 2011 at the Hannover Exhibition. The participants of the event defined it as the implementation of "cyber-physical systems" into industrial processes. While the concept "Industry 3.0" was aimed mostly at the automatization of certain processes and machines, Industry 4.0 provides for the end-to-end digitalization of all physical assets of the enterprise and the integration thereof into the unified ecosystem together with the partners that participate in the added value chain. It is assumed that the computeraided manufacturing will be controlled by intelligence systems, going beyond the boundaries of one enterprise, on a real-time basis at continuous interaction with external environment, with a prospect of unification into a global industrial network of things and services. Industry 4.0 is related to a number of key technologies, such as Industrial Internet of Things, additive manufacturing, Big Data analysis, cyber security and augmented reality [1]. It is expected that these particular technologies will blur the lines between physical, digital and biological spheres.

It might seem that a new paradigm means new opportunities for everybody, but as the history shows, the change of the formation may become a beginning of the end for those enterprises that were not ready for it [2]. In the nearest future, the level of competitiveness will be defined by the ability of the companies to use digital technologies in their manufacturing process, and it is obvious that the transfer to digital economy will lead to unrecognizability of many industries and sectors of economy.

It is evident that the digital economy breaks the usual models of growth for the companies, industries and national economies in general. Understanding this, well-known companies try to implement digital solutions in their operation. Digital platforms constitute a valuable asset and a core of the "new" economy. Modern digital platforms are developed by such famous IT companies as Amazon, eBay, Facebook, iTunes, Airbnb, Tencent, Vkontakte, Yandex, Avito, OZON. Digital platforms are used as the main channels and tools for communicating with clients, making financial transactions, and constitute a kind of a mechanism for creation of innovation business models. Even today we can see how the digital technologies developed by these companies changed the appearance of certain industries and sectors of economy, for example private transportation sector (taxi services), tourism industry and printing industry.

\section{WORLD TRENDS OF DEVELOPMENT OF DIGITAL ECONOMY}

Each country has its own achievements and approaches to creation of digital economy. So far, we cannot observe an absolute leader in the development of all aspects of digital economy, however, Germany is considered to be the leader of industrial technologies and the home of the term "Industry 4.0". Nearly $10 \%$ of population in Germany are engaged in high technology industries. The purposeful state policy and financing of promising digital projects play a key role in the formation of the digital economy in Germany. The main tasks of the state policy in Germany include 
ensuring institutional conditions for the promotion of research activities and developing the fundamental education.

The features of digital economy in Japan and South Korea are formed around famous large corporations such as Toyota, SoftBank, Samsung, LG, etc., where innovation products appear and digital solutions are developed. The startup ecosystem here is less developed, although certain projects in the internet commerce appear (Rakuten) and internet messengers are created (Line, Kakao).

The USA achieved certain success in development of digital technologies in the country. The volume of digital economy in the structure of GDP is fairly high and amounts to $10.9 \%$ (Table 1), which is related, first of all, to extensive investment of private and public sectors to digital technologies. The USA managed to produce innovations on a large scale in many areas of economy.

The economy of China is developing towards the digitalization particularly rapidly and efficiently. Although the economy is still referred to developing countries, its share of digital economy in GDP is comparable to indicators of the USA. The experience of China in commercialization of promising digital projects targeted at the external market, for example, Alibaba, Huawei, proved to be very successful. The countywide digitalization in China resulted in the extensive use by the population of online retail services, digital banking and various online possibilities of ecosystem. The physical retail trading was replaced by electronic commerce resulting in the development of financial online services [4].

When studying the experience of different countries in the development of digital economy and its accompanying technologies, it is necessary to mention that every country has its own way of development but at the same time they all have two common features as favourable conditions for the commercialization of innovation projects and significant volumes of investment capital contributed to the area of information and communication technologies (ICT). Moreover, at the first stages of digitalization, new entrepreneurial opportunities are opened for the companies due to emergence of new market niches and trends (online medical services, online retail services, etc.). Therefore, Russia has a chance of making a technological leap forward in many spheres. For example, we can observe something of the kind in the banking sector where Russian financial institutions managed to escape some remains that were an obstacle to banking systems of developed countries in '80s-'90s, and proceed to the development of digital functional right away.

It is expected that the transition to the digital economy of Russia will be one of the main factors of GDP growth. According to forecasts of experts of McKinsey consulting company [3], the potential effect from the digitalization of the Russian economy for GDP by 2025 is estimated to be $4.1-8.9$ trillion roubles, which will amount to $19-34 \%$ of the total increase of GDP. The priority directions of Russian digitalization include digital ecosystems, digital platforms, 3D-printing, advanced analytics of big data arrays, internet of things, etc. The experience of China and the USA forms certain expectations for the development of digital economy, since these particular countries managed to increase the performance and qualification of labour force, reduce prices by means of competition growth and facilitate the access to obtaining the information.

According to expert investigations, in Russia the share of digital economy in the GDP structure amounts to $3.9 \%$ (Table 1 ), which is $2-3$ times less as compared to the countries being the leaders [3]. On the one hand, such percentage proves the insufficient level of economy digitalization as compared to the world standards, on the other hand, a positive growth dynamics of this indicator may be observed over a period of 5 years. For example, Russia's GDP increased by $7 \%$ from 2011 to 2015 , and the volume of digital economy for the same period increased by $59 \%$ [3]. It is fair to say that the digital economy grows 8.5 times faster than other sectors of economy. The world leader is United Kingdom with the share of digital economy in GDP amounting to $12.4 \%$ following the results of 2016 [4].

TABLE I. Contribution of digital economy into Russia's GDP and its components as compared to other countries, in $\%$ of GDP [5]

\begin{tabular}{|c|c|c|c|c|c|c|}
\hline & $\begin{array}{l}\mathbb{W} \\
\stackrel{\sim}{\nu}\end{array}$ & $\stackrel{\stackrel{\Xi}{\Xi}}{\Xi}$ & 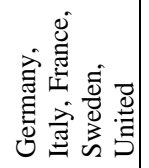 & 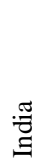 & : & $\begin{array}{l}. \frac{\pi}{5} \\
\stackrel{5}{2} \\
\stackrel{2}{2}\end{array}$ \\
\hline $\begin{array}{l}\text { Expenses of } \\
\text { households in } \\
\text { digital area }\end{array}$ & $\begin{array}{l}5 \\
3\end{array}$ & 4.8 & 3.7 & 3.2 & 2.7 & 2.6 \\
\hline $\begin{array}{l}\text { Investments } \\
\text { of companies } \\
\text { into } \\
\text { digitalization }\end{array}$ & 5 & 1.8 & 3.9 & 2.7 & 3.6 & 2.2 \\
\hline $\begin{array}{l}\text { Government } \\
\text { expenses on } \\
\text { digitalization }\end{array}$ & \begin{tabular}{l|}
1 \\
3 \\
\end{tabular} & 0.4 & 1.0 & 0.6 & 0.8 & 0.5 \\
\hline $\begin{array}{l}\text { Export of } \\
\text { ICT }\end{array}$ & $\begin{array}{l}1 \\
4 \\
4\end{array}$ & 5.8 & 2.5 & 2.9 & 0.1 & 0.5 \\
\hline $\begin{array}{l}\text { Import of } \\
\text { ICT }\end{array}$ & $\begin{array}{l}- \\
2 \\
\dot{1}\end{array}$ & -2.7 & -2.9 & $\overline{-}-1$ & $\begin{array}{l}- \\
1.0\end{array}$ & -1.8 \\
\hline $\begin{array}{l}\text { Total amount } \\
\text { of digital } \\
\text { economy }\end{array}$ & $\begin{array}{l}1 \\
0 \\
9\end{array}$ & 10 & 8.2 & 6.3 & 6.2 & 3.9 \\
\hline
\end{tabular}

Expense of Russian households in digital area amount to $2.6 \%$ of GDP, that is approximately 2 times less than in the USA and China. They consist of the costs related to the use of electronic commerce possibilities and purchase of digital devices, as well as other digital expenses, such as payment for the 
Internet, payment for the services made by means of mobile applications, etc. The electronic commerce that was growing at fast pace during the past years accounts for the half digital expenses of Russian households: the annual growth of electronic commerce in Russia during the last several years amounted to $20 \%$, while certain categories, for example, online sales in tourism area grew by $30 \%$.

As regards to the indicator "investments of private companies" in digitalization, so far Russia falls behind the countries being the leaders. In Russia, this indicator amounts to $2.2 \%$ of GDP, in the USA $-5 \%$, in countries of Western Europe - 3.9\%, in Brazil $3.6 \%$ (see Table 1). The share of export of digital goods and services is an important indicator for the evaluation of digital economy efficiency. The share of export in general reflects the competitiveness of national products on the world market and the degree of integration of the economy into world economic processes. As it follows from schedule 1, the percent of export of digital solutions amounts to $0.5 \%$ in the structure of GDP. In China and India the same indicator reaches the level of 5.8 and 2.9 respectively. It is obvious that a relatively low volume of export does not correspond to the digital economy standards.

However, despite of fairly low indicators as compared to other countries, Russia still has certain results in the area of digitalization. Famous large enterprises Rosatom, Rostec, Sberbank became pioneers in the implementation of digital solutions. Many of them not only deploy the technologies, but are also engaged in the development of their own solutions. The experience of Gazprom Neft, that for several years has been reforming its production facilities according to a new model, may serve as an interesting example of putting Industry 4.0 concept in operation. Vnesheconombank defined blockchain technologies as the priority direction of development. In 2017 blockchain projects were launched with the Pension Fund, Rospatent. Digital Economy ANO was established, which has among its members such companies as Mail.ru, Yandex, Rambler, Megafon, VimpelCom, MTS, etc. Also, a number of private companies that were established virtually from scratch achieved some success: for example, Tinkoff Bank online bank that does not have physical branches and that has become the largest independent bank in the world just in 10 years; Kaspersky company specialising in production of digital solutions in security area; digital portals and ecosystems of Yandex and Mail.ru services; Avito electronic announcement platform.

Due to a globally emerging trend, the government policy targeted at digitalization significantly improved the quality of public services and made them more accessible for citizens and for the business. The level of digitalization of public services in Russia is slightly lower the indicators of countries being the leaders. The level of government expenses on information and communication technologies in the structure of GDP is comparable to China, India, but is two times less than in the USA and Western Europe. For the last several years, Russia created government digital platforms that are comparable with similar systems in the leading countries, and sometimes even surpassing their services: obtaining a passport or driver's license, vehicle registration, school enrollment, payment of taxes and fines and many others. Following the results of 2016, nearly half of all public and municipal services may be obtained in electronic form, and more than $50 \%$ of people applying for those services prefer to obtain them in electronic form.

\section{PROBLEMS OF RUSSIAN DIGITALISATION}

The development of digital economy in Russia was mentioned for the first time in the message of the President to the Federal Council in December 2016. The President of the Russian Federation pointed out the need to form a new web-economy in order to increase the industry efficiency by means of information technologies. Within the policy outlined by the President the Government prepared a "Digital Economy" program that was approved in July 2017. It is obvious that the approved program not only showed the intent of the government to be in line with the global trends, but also set a goal to integrate into the world reality using the technologies of Industry 4.0 project. The main task of digital transformation of Russian economy is to improve the quality of life of the population by making high quality products produced using modern digital technologies.

For the implementation of the Digital Economy program, first of all, it is necessary to define the technological focus and only then to concentrate the investment capital for the goals set. The correct goal setting is a guarantee of success for any action. All the more, the promising directions are already globally formulated and clear. Probably, in order to reach the maximum effect the accent should be made on the development of those technologies where Russia has strong competencies, for example, IT industry. Investments in those technologies where the competitive advantage already exists will bring better results as compared to the development from scratch.

Secondly, most probably, the Russian economy will have to meet two challenges at the same time: modernization and technological leap. Both challenges imply two scenarios: catching-up and outstripping. In case of catching-up scenario, investments in downstream industries, infrastructure facilities and export shall be made. The catching-up scenario does not imply technological advances. The outstripping development centers around innovation projects related to blockchain technologies, quantum technologies, scaling, market place and other B2B.

The difficulty of digital transformation is connected not only with the choice of proper technologies and priorities. The problem is rooted in the insufficient maturity of digital culture in the society and at enterprises. According to the information of Digital IQ-2017 research, the investments in breakthrough technologies have a 
fundamental meaning; however, eventually the success and efficiency of digital transformation will depend on a broad range of factors related to people, and not on sensors and analytics tools. In keeping with this approach, the task will be to form the digital culture and the conditions for the personal interest in the digital transformation on the part of companies' personnel and management. The digital economy is the environment that will be forming for several years and will need the engagement of competencies of many skilled specialists.

However, the growing economy digitalization sets to the industries and the government new tasks that they have not encountered before. As and when digital automation and robot systems are introduced with the resulting increase of labor productivity, the physical services will be replaced by digital services. As consequence, a number of specialties and professions may be at the risk of extinction. According to the research of McKinsey institute, by 3036 up to $50 \%$ of jobs will be automated. First of all, this will apply to the jobs that require average qualifications, because it is easier to automate the types of jobs that are connected with performance of predictable repeated physical operations and jobs related to information gathering and analysis. In keeping with this approach, the digitalization of the Russian economy requires from employees and employers to adjust to new conditions.

At the same time digital technologies and platforms may have a significant positive influence on the labor market: they will facilitate the personnel hiring process, reduce the period of searching for a job, increase the productivity of employees, improve the situation with engagement of personnel in the economy with the help of remote jobs and provide access to the quality education. The task of the government in this case will include the timely coordination of actions related to training and employment of released personnel.

\section{CONCLUSION}

The creation and improvement of new technologies takes place so quickly that it seems to be impossible to use old technologies within the digitalization of global economic processes. This is such a moment when it is expedient to enter to maximum extent possible into the general information and technological stream of global digital changes and try to use them efficiently in the national economic environment.

So far, Russia has been able to hold the leading positions in terms of hydrocarbons and grain products export. The fact that Russia missed the third industrial revolution and as a result became a consumer of innovation solutions and not a producer of high technologies worsens the situation. There exist unresolved problems related to commercialization of breakthrough inventions and infrastructure that is highly needed for innovations. We may ascertain only specific innovation results of particular companies.
Corporate structures that have a margin of financial safety and potential are often not interested in innovation solutions. As a result, we face a global problem: the economy is able to generate knowledge and make discoveries but is not able to commercialize the obtained results and incorporate into the global market so far.

The spread of digital technologies at "natural rates" in Russia will not bring the intended results, and the absence of well-directed efforts will only worsen falling behind the countries that will manage to catch a wave of digital revolution. Against the background of the world events, it is necessary to develop a smoothly running mechanism for the achievement of the goals set that will be based on close integration and efficient cooperation of the science, government and business.

\section{REFERENCES}

[1] Тарасов И.В. Технологии Индустрии 4.0: влияние на повышение производительности промышленных компаний // Стретегические решения и риск-менеджмент. 2018. №2. C. 62-69. [Tarasov V. Technologies of 4.0 Industry: Influence on the Improvement of Performance of Industrial Companies // Strategical Solutions and RiskManagement. 2018. N 2. P. 62-69].

[2] Трачук А.В., Линдер Н.В. (2017а). Инновации и производительность российских промышленных компаний // Инновации. №4 (222). C. 53-65. [Trachuk A.V., Linder N.V. Innovations and Performance of Russian Industrial Companies // Innovations. 2017. N 4(222). P. 53-65].

[3] Цифровая Россия: новая реальность. 2017. [Digital Russia: New Reality. 2017]. URL: https://www.mckinsey.com/ /media/McKinsey/Locations/Eu rope\%20and\%20Middle\%20East/Russia/Our\%20Insights/Di gital\%20Russia/Digital-Russia-report.ashx.

[4] Цифровая экономика:глобальные тренды и практика российского бизнеса. [Report "Digital Economy: Global Trends and Experience of Russian Business"]. URL: https://imi.hse.ru/data/2017/10/06/1159517769/!Цифровая\% 20 экономика $\% 20$ -

\%20глобальные\%20тренды\%20и\%20практика\%20россий ского\%20бизнеса.pdf. 